\title{
A hybrid method for generation of attenuation map for MR-based attenuation correction of PET data in prostate PET/MR imaging
}

\author{
Mehdi Shirin Shandiz', Mohammad Hadi Arabi ${ }^{1}$, Pardis Ghafarian², Mehrdad Bakhshayesh Karam², \\ Hamidreza Saligheh Rad ${ }^{1}$, Mohammad Reza Ay ${ }^{1 *}$
}

From PSMR14: 3rd Conference in PET/MR and SPECT/MR

Kos Island, Greece. 19-21 May 2014

${ }^{1}$ Department of Medical Physics and Biomedical Engineering and Research Center for Molecular and Cellular Imaging, Tehran University of Medical Sciences, Tehran, Iran
Recently introduced PET/MRI scanners present significant advantages in comparison with PET/CT. However, the lack of accurate method for generation of $\mu$ map from MR images for implementation of MRAC is hampering further development. In this study, we present a new method including short echo-time pulse sequence to detect bone signal along with a robust and automatic image segmentation method base on FCM, active contouring and shape analysis to provide a three-classes $\mu$ map. The proposed imaging protocol implemented on a 1.5T Avanto scanner. The acquisition parameters were $1.11 \mathrm{msec}$ and $20 \mathrm{msec}$ for $\mathrm{TE}$ and TR, respectively, with $\mathrm{FA}=20$. The image-processing protocol includes five major steps: (I) intensity-inhomogeneity correction using non parametric method, which is an essential step for removing bias field; (II) separation of bone and air from other areas using active contouring based on gradient vector method; (III) FCM in order to segment the image into two clusters, one cluster is bone and air and another cluster is soft tissue; (IV) separation of bone and air areas using shape analysis; $(\mathrm{V})$ generation of $\mu$ map. The accuracy of the proposed segmentation method was validated using comparison against manual segmentation. The corresponding segmentation images and generated $\mu$ map prove the validity of algorithm. Quantitative analysis on accuracy, sensitivity and specificity for 15 segmented images in comparison with manual segmentation performed by an expert radiologist. The proposed strategy shows that the three tissue class $\mu$ map can be successfully generated from MR images in pelvis region using STE pulse sequence following by the image processing steps. The method can be a potential alternative to UTE-based attenuation correction. The algorithm is still under development and will be validated in more details based on comparison with the $\mu$ maps generate from CT images. This study has been developed particularly for improving the accuracy of MRAC in prostate imaging.

\section{Authors' details}

${ }^{1}$ Department of Medical Physics and Biomedical Engineering and Research Center for Molecular and Cellular Imaging, Tehran University of Medical Sciences, Tehran, Iran. ${ }^{2}$ Chronic Respiratory Disease Research Center, NRITLD and PET/CT and Cyclotron Center, Masih Daneshvari Hospital, Shahid Beheshti University of Medical Sciences, Tehran, Iran.

\section{SpringerOpen ${ }^{\circ}$}

(C) 2014 Shandiz et al; licensee Springer This is an Open Access article distributed under the terms of the Creative Commons Attribution License (http://creativecommons.org/licenses/by/4.0), which permits unrestricted use, distribution, and reproduction in any medium, provided the original work is properly cited. 
doi:10.1186/2197-7364-1-S1-A77

Cite this article as: Shandiz et al: A hybrid method for generation of attenuation map for MR-based attenuation correction of PET data in prostate PET/MR imaging. EJNMMI Physics 2014 1(Suppl 1):A77.

Submit your manuscript to a SpringerOpen ${ }^{\odot}$ journal and benefit from:

- Convenient online submission

- Rigorous peer review

- Immediate publication on acceptance

- Open access: articles freely available online

- High visibility within the field

- Retaining the copyright to your article

Submit your next manuscript at $\boldsymbol{\nabla}$ springeropen.com 